\title{
Occurrence and Health Risk Assessment of Trace Metals in Desalinated Seawater Using Two Desalination Technologies
}

\author{
Bo Gao ${ }^{1,2 *}$, Hongjing Yu ${ }^{1}$ Jijun Gao ${ }^{2}$, Linghua Liu ${ }^{1,2}$, Qiwen Wang², \\ Cheng Zhu' ${ }^{1}$, Wenqiang $\mathrm{Wu}^{2}$ \\ ${ }^{1}$ State Key Laboratory of Simulation and Regulation of Water Cycle in River Basin, \\ Chinese Institute of Water Resources and Hydropower Research, Beijing, China \\ ${ }^{2}$ Department of Water Environment, Chinese Institute of Water Resources and Hydropower Research, \\ Beijing, China
}

Received: 22 June 2019

Accepted: 8 October 2019

\begin{abstract}
Desalination of seawater is an effective way to alleviate the world's water shortage. However, the transmission and health risk of trace metals in the different processes of seawater plants are highly uncertain. Here, we investigated the concentrations of 29 ions and trace elements in desalinated water based on two desalination techniques - multiple effect distillation (MED) and reverse osmosis (RO) and evaluated the potential health risks (carcinogenic risk (CR) and non-carcinogenic risk (n-CR)) of trace metals in these processes. The results showed that most ions and trace elements were efficiently removed using both the RO and MED methods. After desalination, the trace metal concentrations in the desalinated water treated with the MED method were higher than those in the desalinated water treated with the RO method. The $\mathrm{n}-\mathrm{CR}$ values for the trace metals in the desalinated water using the MED and RO methods were within the neglectable level. The CR values based on the two methods were lower than the maximal acceptable risk levels designated by the US Environmental Protection Agency. The total health risks using the MED method were higher than those using the RO method. Our results indicated that seawater desalination using both treatment methods is safe.
\end{abstract}

Keywords: desalination, seawater, health risk assessment, trace metals, reverse osmosis

\section{Introduction}

Water demand and the water shortage crisis are increasing worldwide due to the population and rapid

*e-mail: gaobo@iwhr.com growth of the global economy, which are becoming very serious social and environmental problems [1]. According to the World Health Organization, by the year 2025 approximately $50 \%$ of the world's population will live in water-stressed regions. Therefore, other alternative methods (utilizing desalted seawater or recycling wastewater) have been invented for efficient water consumption [2]. Desalination of seawater is 
believed to be a reliable and pragmatic option to alleviate this situation, which is an emerging water resource to meet fresh water demands [3]. According to the International Desalination Association, 150 countries with a total of 18,426 desalination plants are operating worldwide, producing 40 million cubic meters per day $\left(\mathrm{Mm}^{3} /\right.$ day) in $2013,86.8 \mathrm{Mm}^{3} /$ day in 2015 , and reaching $88.6 \mathrm{Mm}^{3} /$ day in 2016 , providing water for 300 million people [4, 5]. Many countries with water shortage problems, such as Japan, Australia, Spain, China, and the USA, have already developed this new water resource [6]. China is also one of the largest water shortage areas in the world [1]. In 2014, more than 400 of 561 Chinese cities were deficient in water to some extent [7]. Statistically, by the end of 2016 more than 100 seawater desalination projects were completed in China, with a water production scale of 1.89 million tons per day and the largest seawater desalination project scale of 200,000 tons per day [8]. Electrodialysis (ED) and reverse osmosis (RO) methods are the two commonly used seawater desalination technologies [9, 10]. In fact, research on this topic was started in 1958 and 1965 in China [11, 12]. The Institute of Seawater Desalination and Multipurpose Utilization was also established in Tianjin in 1984. Since then, desalination technologies have significantly improved. In China, most of the completed desalination plants are located in Liaoning, Shandong, Hebei, Tianjin, and Zhejiang [7, 13].

Although seawater desalination has been widely used in many countries worldwide, its drawbacks are also obvious. For example, low water alkalinity and hardness and high salinity can lead to the corrosion of the facilities and water-transmission pipeline [14]. If desalinated seawater enters the municipal metal pipeline, the health risk of trace metals in the drinking water will be increased significantly. Therefore, health risk assessment of trace metals in desalinated water is essential for drinking water safety. However, previous studies have mainly focused on desalination technologies $[15,16]$ and the economic cost accounting and evaluation of project investments [17, 18]. Little research has been conducted on evaluating the health risks caused by trace metals during the process of seawater desalination, a topic that deserves further evaluation.

In this study, water samples were collected in two desalination plants in Northern China based on two typical desalination techniques (multiple effect distillation (MED) and RO). The objectives of the present study were to: (1) investigate the occurrence of trace metals in desalinated water based on the two desalination methods; (2) compare the trace metal concentrations in different process sections with the drinking water sanitary standard; and (3) evaluate the potential health risk (carcinogenic risk (CR) and noncarcinogenic risk (n-CR)) of trace metals in desalinated seawater.

\section{Materials and Methods}

\section{Sample Collection}

Water samples were collected from two desalination plants in Northern China based on the MED and RO methods in March 2017. In one desalination plant using the MED method, both seawater and desalted water were collected. In another desalination plant using the RO method, seawater, primary RO, secondary RO and desalted water were collected. At each sampling site, three water samples were collected. The water samples were collected in polymer polyethylene bottles, and transported to the laboratory. Thereafter, the water samples were filtered through 0.45 - $\mu \mathrm{m}$ filter membranes and then acidified with ultrapure concentrated $\mathrm{HNO}_{3}$ to a $\mathrm{pH}$ lower than 2. All the water samples were stored at $4^{\circ} \mathrm{C}$ until analyzed. The trace metal concentrations and other ions were measured using inductively coupled plasma-mass spectrometry (ICP-MS, Agilent 7700x) and ion chromatography (ICS-3000, Dionex). Hg was measured using an atomic fluorescence spectrometer (AFS-2202E, Beijing Haiguang Instrument Co., Ltd., Beijing, China). For quality control, the calibration curve was prepared using the mixed standard sample (GB1767). A standard reference material (Trace Element in Water, Agilent) was analyzed to check the accuracy of measurement. The recovery rate was within the recommended range $(90-110 \%)$.

\section{Health Risk Assessment}

In this study, human health risk was assessed by applying US EPA methodology [19]. Human beings can be exposed to trace metals in water through direct ingestion and dermal absorption by the skin [20]. Compared with the other pathway, direct ingestion through drinking water is the most direct exposure route. According to the toxic characteristics of pollutants, health risk assessment includes n-CR and CR. In this study, $\mathrm{Pb}, \mathrm{Zn}, \mathrm{Cu}, \mathrm{Mn}, \mathrm{Ni}, \mathrm{Hg}$, and $\mathrm{Se}$ are non-carcinogens, and $\mathrm{Cd}$, $\mathrm{As}$ and $\mathrm{Cr}$ are carcinogens. Human life can be divided into four stages: infant, teenager, adult, and elderly populations.

The $n-C R$ is calculated by Eq. (1):

$$
\begin{gathered}
\mathrm{R}^{\mathrm{n}}=\sum_{k=1}^{k} R_{k}^{n} \\
R_{k}{ }^{n}=\left(\mathrm{D}_{\mathrm{k}} / \mathrm{R}_{\mathrm{f}} \mathrm{D}_{\mathrm{k}}\right) \times 10^{-6} / \mathrm{Y} \\
\mathrm{D}_{\mathrm{k}}=\mathrm{Q}_{\mathrm{i}} \times \mathrm{C}_{\mathrm{k}} / \mathrm{W}_{\mathrm{i}}
\end{gathered}
$$

...where $\mathrm{R}^{\mathrm{n}}$ is the total $\mathrm{n}-\mathrm{CR}$ caused by non-carcinogens; $R_{k}{ }^{n}$ is the average year of $\mathrm{n}-\mathrm{CR}$ of metal $\mathrm{k}$ by ingestion $\left(a^{-1}\right)$; and $\mathrm{R}_{\mathrm{f}} \mathrm{D}_{\mathrm{k}}$ is the reference dose of the metal $\mathrm{k}(\mathrm{mg} /(\mathrm{kg} \cdot \mathrm{d}))$. 
The CR is calculated by the following equations:

$$
\begin{gathered}
R^{\mathrm{c}}=\sum_{j=1}^{j} R_{j}^{c} \\
R_{j}^{c}=\left[1-\exp \left(-\mathrm{D}_{\mathrm{j}} \times q_{\mathrm{j}}\right)\right] / \mathrm{Y} \\
\mathrm{D}_{\mathrm{j}}=\mathrm{Q}_{\mathrm{i}} \times \mathrm{C}_{\mathrm{j}} / \mathrm{W}_{\mathrm{i}}
\end{gathered}
$$

...where $R^{\mathrm{c}}$ is the total $\mathrm{CR}$ caused by carcinogens; $R_{j}^{c}$ is the average years of $\mathrm{CR}$ of the metal $\mathrm{j}$ by drinking water $\left(a^{-1}\right) ; D_{j}$ is the daily exposure dose of metal $j$, $(\mathrm{mg} /(\mathrm{kg} \cdot \mathrm{d})) ; q_{\mathrm{j}}$ is the carcinogenic factor of metal $\mathrm{j}$, $(\mathrm{mg} /(\mathrm{kg} \cdot \mathrm{d}))$; and $\mathrm{Y}$ is the average lifetime (75.76 a). $\mathrm{Q}_{\mathrm{i}}$ is daily water consumption (L); $\mathrm{C}_{\mathrm{j}}$ is the concentration of metal $\mathrm{j}(\mathrm{mg} / \mathrm{L})$; and $\mathrm{W}_{\mathrm{i}}$ is body weight.

The hypothesis is that no synergistic relationship exists among the toxicities of the trace metals, and that total health risk is the sum of the n-CR and CR:

$$
R=R^{\mathrm{n}}+R^{\mathrm{c}}
$$

The values of model parameters $\mathrm{q}_{\mathrm{i}}$ and $\mathrm{R}_{\mathrm{f}} \mathrm{D}_{\mathrm{i}}$ are exhibited in Table 1, and the values of $\mathrm{Y}, \mathrm{Q}$ and $\mathrm{W}$ are shown in Table 2 [21].

\section{Results and Discussion}

\section{Inorganic and Ion Parameters in Seawater before and after Desalination}

MED has been used in process industries for a long time. Recently, the MED low-temperature operation using a thermal vapor compressor was developed [22]. The inorganic parameters in the seawater and desalted water are listed in Table 3. Relatively high removal efficiencies existed for the inorganic salt using both $\mathrm{RO}$ and MED. The removal of $\mathrm{Na}^{+}, \mathrm{K}^{+}, \mathrm{Mg}^{2+}$ and other negative ions all reached $99.9 \%$ by both the RO and MED methods, indicating that these two desalination

Table 1. Values of model parameters $\mathrm{q}_{\mathrm{i}}$ and $\mathrm{R}_{\mathrm{f}} \mathrm{D}_{\mathrm{k}}[18]$.

\begin{tabular}{|c|c|c|c|}
\hline Carcinogens & $\begin{array}{c}q_{i} \\
(\mathrm{mg} /(\mathrm{kg} \cdot \mathrm{d}))\end{array}$ & $\begin{array}{c}\text { Non-Carcin- } \\
\text { ogens }\end{array}$ & $\begin{array}{c}\mathrm{R}_{\mathrm{f}} \mathrm{D}_{\mathrm{k}} \\
(\mathrm{mg} /(\mathrm{kg} \cdot \mathrm{d}))\end{array}$ \\
\hline $\mathrm{Cd}$ & 6.1 & $\mathrm{~Pb}$ & $1.4 \times 10^{-3}$ \\
\hline $\mathrm{As}$ & 15 & $\mathrm{Zn}$ & 0.3 \\
\hline $\mathrm{Cr}$ & 41 & $\mathrm{Cu}$ & $5 \times 10^{-3}$ \\
\hline & & $\mathrm{Mn}$ & 0.02 \\
\hline & & $\mathrm{Sb}$ & $4 \times 10^{-4}$ \\
\hline & & $\mathrm{Ni}$ & 0.02 \\
\hline & & $\mathrm{Hg}$ & $4 \times 10^{-4}$ \\
\hline & & $\mathrm{Se}$ & 0.01 \\
\hline
\end{tabular}

Table 2. Associated parameters in health risk assessment [18].

\begin{tabular}{|c|c|}
\hline Parameter & Value \\
\hline $\mathrm{Y}$ & $75.76 \mathrm{a}$ \\
\hline $\mathrm{Q}$ & $1.0 \mathrm{~L} / \mathrm{d}_{\mathrm{i}} ; 2.0 \mathrm{~L} / \mathrm{d}_{\mathrm{ii}} ; 3.2 \mathrm{~L} / \mathrm{d}_{\mathrm{iii}} ; 2.7 \mathrm{~L} / \mathrm{d}_{\mathrm{iv}}$ \\
\hline $\mathrm{W}$ & $18.9 \mathrm{~kg} ; 44.4 \mathrm{~kg} ; 63.1 \mathrm{~kg} ; 62.2 \mathrm{~kg}$ \\
\hline
\end{tabular}

i: infant; ii teenager; iii: adult; iv: the elderly

techniques have high efficiencies in removing the above inorganic ions. Moreover, the removal of $\mathrm{B}$ by the RO method was higher than that by the MED method, resulting from the high elution membrane of $\mathrm{B}$ added to the second process of the RO method. Additionally, the $\mathrm{pH}$ value of the $\mathrm{RO}$ method was higher than that of the MED method (Table 3) and was attributed to the increase in the $\mathrm{pH}$ value in the second process of the RO method being the best method to control B concentrations. Thus, if the removal rate of $B$ was increased by the MED method, the subsequent treatment technique should be coupled with the MED method.

Removal rate using the $\mathrm{RO}$ method ranged from $55.91 \%$ to $100 \%$ for most trace metals, values that were higher than those using the MED method. Notably, Al, $\mathrm{Fe}, \mathrm{Zn}$ and $\mathrm{Se}$ concentrations in the second process by the RO method increased compared with that in the first process (Table 3 ) due to the addition of chemical reagents to prevent the pipeline's erosion by the RO method. A similar result was also found in a previous study [23]. In addition, $\mathrm{Hg}$ removal rate using the $\mathrm{RO}$ method was only $38.78 \%$, and $\mathrm{Hg}$ concentrations in the first $(0.015$ $\mu \mathrm{g} / \mathrm{L})$ and second $(0.011 \mu \mathrm{g} / \mathrm{L})$ processes using the RO method were not obviously different from that of the seawater $(0.018 \mu \mathrm{g} / \mathrm{L})$, indicating that the residual $\mathrm{Hg}$ in the pipeline using the RO method should not be ignored (Table 3). In addition to inorganic contaminants, different types of organics can also be found in water (e.g., pesticides, herbicides, and personal care products) released by human activities [24]. Therefore, organics are important targets for membrane water treatment. In the last decade, the RO method also has been applied to remove synthetic organic matter [25]. However, due to the low-water permeability of its membranes, the removal rate was low. Further technology should develop high-permeability membranes.

\section{Comparison of Trace Metals Concentrations \\ in Desalted Water to Water Quality Standards}

Comparison of different water quality standards to desalinated water is shown in Table 4 . Before the desalted water was injected into the municipal pipeline, the metal concentrations of the desalted water should be detected to ensure drinking water quality. Comparison of the trace metal concentrations ( $\mathrm{As}, \mathrm{Cd}, \mathrm{Pb}$ and $\mathrm{Hg}$ ) of desalted water to the standard of drinking water quality in China revealed that the trace metal concentrations 
Table 3. Removal comparison of inorganic parameters to different treatment methods.

\begin{tabular}{|c|c|c|c|c|c|c|c|c|}
\hline \multirow[b]{2}{*}{ Parameters } & \multicolumn{5}{|c|}{ RO method } & \multicolumn{3}{|c|}{ MED method } \\
\hline & Seawater & First process & Second process & $\begin{array}{c}\text { Desalinated } \\
\text { water }\end{array}$ & $\begin{array}{c}\text { Removal } \\
(\%)\end{array}$ & Seawater & $\begin{array}{c}\text { Desalinated } \\
\text { water }\end{array}$ & $\begin{array}{c}\text { Removal } \\
(\%)\end{array}$ \\
\hline $\mathrm{Na} \mathrm{mg} / \mathrm{L}$ & 10781.1 & 151.403 & 1.8598 & 0.2773 & 99.99 & 9711.5 & 1.2021 & 99.988 \\
\hline $\mathrm{K} \mathrm{mg} / \mathrm{L}$ & 392.8 & 6.406 & 0.0664 & 0.0083 & 99.998 & 320.8 & 0.0076 & 99.998 \\
\hline $\mathrm{Mg} \mathrm{mg/L}$ & 1089.9 & 3.437 & 0.0917 & 0.0306 & 99.997 & 963.8 & 0.0444 & 99.995 \\
\hline $\mathrm{Ca} \mathrm{mg} / \mathrm{L}$ & 421.7 & 4.651 & 2.7589 & 2.4515 & 99.419 & 499.6 & 2.0742 & 99.585 \\
\hline $\mathrm{F}^{-} \mathrm{mg} / \mathrm{L}$ & 48.4 & 0.0011 & 0.0007 & 0.0384 & 99.921 & 8.2 & 0.0019 & 99.977 \\
\hline $\mathrm{Cl}^{-} \mathrm{mg} / \mathrm{L}$ & 20206.8 & 269.432 & 1.899 & 0.3597 & 99.998 & 15641.1 & 0.575 & 99.996 \\
\hline $\mathrm{SO}_{4}^{2-} \mathrm{mg} / \mathrm{L}$ & 2309.8 & 6.9305 & 0.1876 & 0.0545 & 99.998 & 1778.3 & 0.4301 & 99.976 \\
\hline $\mathrm{NO}_{3}{ }^{-} \mathrm{mg} / \mathrm{L}$ & 2.6 & 0.0014 & 0.0012 & 0.0009 & 99.965 & 3.1 & 0.0003 & 99.990 \\
\hline $\mathrm{CO}_{3}{ }^{2-} \mathrm{mg} / \mathrm{L}$ & 39.234 & 9.125 & 5.435 & 3.827 & 90.246 & 33.845 & 4.657 & 86.240 \\
\hline B mg/L & 4.107 & 0.91 & 0.089 & 0.087 & 97.882 & 3.42 & 0.37 & 89.181 \\
\hline $\mathrm{Li} \mu \mathrm{g} / \mathrm{L}$ & 20.533 & 2.065 & 0.088 & 0.045 & 99.78 & 37.943 & 0.114 & 99.70 \\
\hline $\mathrm{Al} \mu \mathrm{g} / \mathrm{L}$ & L.D. & L.D. & 337.761 & L.D. & -- & -- & -- & -- \\
\hline $\mathrm{V} \mu \mathrm{g} / \mathrm{L}$ & 2.608 & 0.070 & 0.051 & 0.007 & 99.75 & 18.785 & 5.431 & 71.09 \\
\hline $\mathrm{Cr} \mu \mathrm{g} / \mathrm{L}$ & 0.776 & 0.094 & 0.063 & 0.045 & 94.15 & 0.926 & 1.140 & \\
\hline $\mathrm{Mn} \mu \mathrm{g} / \mathrm{L}$ & 2.581 & 0.311 & 0.945 & 0.182 & 92.95 & 3.100 & 0.249 & 91.97 \\
\hline $\mathrm{Fe} \mu \mathrm{g} / \mathrm{L}$ & 1.836 & 0.204 & 2.927 & 0.810 & 55.91 & -- & -- & -- \\
\hline Co $\mu \mathrm{g} / \mathrm{L}$ & 0.157 & 0.012 & 0.011 & 0.011 & 92.71 & 0.982 & 0.012 & 98.78 \\
\hline $\mathrm{Ni} \mu \mathrm{g} / \mathrm{L}$ & 0.803 & 0.314 & 0.094 & 0.123 & 84.73 & 33.553 & 0.167 & 99.50 \\
\hline $\mathrm{Cu} \mu \mathrm{g} / \mathrm{L}$ & 2.138 & 0.013 & 0.126 & L.D. & -- & 23.373 & 0.404 & 98.27 \\
\hline $\mathrm{Zn} \mu \mathrm{g} / \mathrm{L}$ & 0.014 & 0.490 & 0.714 & 0.997 & -- & 2.082 & 1.845 & 11.38 \\
\hline $\mathrm{Ga} \mu \mathrm{g} / \mathrm{L}$ & 0.004 & 0.003 & 0.055 & L.D. & -- & 0.321 & 0.068 & 78.82 \\
\hline As $\mu \mathrm{g} / \mathrm{L}$ & 1.405 & L.D. & L.D. & L.D. & -- & 22.659 & 1.379 & 93.91 \\
\hline Se $\mu \mathrm{g} / \mathrm{L}$ & L.D. & 0.090 & 0.218 & 0.080 & -- & -- & -- & -- \\
\hline $\mathrm{Rb} \mu \mathrm{g} / \mathrm{L}$ & 56.890 & 1.900 & 0.023 & 0.026 & 99.95 & -- & -- & -- \\
\hline $\mathrm{Cd} \mu \mathrm{g} / \mathrm{L}$ & L.D. & L.D. & L.D. & L.D. & -- & 0.069 & 0.024 & 65.22 \\
\hline $\mathrm{Tl} \mu \mathrm{g} / \mathrm{L}$ & L.D. & L.D. & L.D. & L.D. & -- & 0.014 & 0.006 & 57.14 \\
\hline $\mathrm{Pb} \mu \mathrm{g} / \mathrm{L}$ & L.D. & L.D. & L.D. & L.D. & -- & 0.020 & 0.012 & 40.00 \\
\hline $\mathrm{U} \mu \mathrm{g} / \mathrm{L}$ & 1.058 & 0.004 & 0.002 & 0.001 & 99.94 & -- & -- & -- \\
\hline $\mathrm{Hg} \mu \mathrm{g} / \mathrm{L}$ & 0.018 & 0.015 & 0.011 & 0.011 & 38.78 & L.D. & L.D. & -- \\
\hline
\end{tabular}

were all below the standard values $(0.01 \mathrm{mg} / \mathrm{L}$ for As, $0.005 \mathrm{mg} / \mathrm{L}$ for $\mathrm{Cd}, 0.01 \mathrm{mg} / \mathrm{L}$ for $\mathrm{Pb}$ and $0.001 \mathrm{mg} / \mathrm{L}$ for $\mathrm{Hg}$ ) (GB 5749-2006) [26]. For major metals (Al, Fe, Mn, $\mathrm{Cu}$ and $\mathrm{Zn}$ ), the $\mathrm{Al}$ and $\mathrm{Cu}$ concentrations in seawater treated using the RO method were all lower than the detection limit. The concentrations of other elements were all lower that the standards of the GB 5749-2006 and standard of drinking water quality in Canada (TEL) [27]. The seldom monitored trace metals $(\mathrm{Sb}, \mathrm{Ba}, \mathrm{Be}$, $\mathrm{B}, \mathrm{Ni}$ and $\mathrm{Tl}$ ) showed similar results indicating that seawater treated using these two treatment techniques
(MED and RO methods) all reached the drinking water standard in China (GB 5749-2006). Notably, the metal (As, $\mathrm{Mn}, \mathrm{Cu}, \mathrm{Zn}, \mathrm{Be}, \mathrm{B}$ and $\mathrm{Tl}$ ) concentrations of desalted water treated using the MED method were higher than those using the RO method, indicating that the RO method might be better than the MED method.

\section{Health Risk Assessment}

The $\mathrm{n}$-CR values for the trace metals in the desalted water using the MED and RO methods are presented in 
Table 4. Comparison of trace metals in desalted water to different water quality standards.

\begin{tabular}{|c|c|c|c|c|}
\hline Elements & ${ }^{\mathrm{a}}$ GB 5749-2006 & ${ }^{\mathrm{b}} \mathrm{TEL}$ & MED method & RO method \\
\hline As (mg/L) & 0.01 & 0.025 & 0.0014 & 'L.D. \\
\hline $\mathrm{Cd}(\mathrm{mg} / \mathrm{L})$ & 0.005 & 0.005 & 0.00002 & L.D. \\
\hline $\mathrm{Pb}(\mathrm{mg} / \mathrm{L})$ & 0.01 & 0.01 & 0.00001 & L.D. \\
\hline $\mathrm{Hg}(\mathrm{mg} / \mathrm{L})$ & 0.001 & 0.001 & L.D. & 0.00001 \\
\hline $\mathrm{Se}(\mathrm{mg} / \mathrm{L})$ & 0.01 & 0.01 & L.D. & 0.0001 \\
\hline $\mathrm{Al}(\mathrm{mg} / \mathrm{L})$ & 0.2 & & L.D. & L.D. \\
\hline $\mathrm{Fe}(\mathrm{mg} / \mathrm{L})$ & 0.3 & $\leq 0.3$ & L.D. & 0.0008 \\
\hline $\mathrm{Mn}(\mathrm{mg} / \mathrm{L})$ & 0.1 & $\leq 0.05$ & 0.0002 & 0.0002 \\
\hline $\mathrm{Cu}(\mathrm{mg} / \mathrm{L})$ & 1.0 & $\leq 1.0$ & 0.0004 & L.D. \\
\hline $\mathrm{Zn}(\mathrm{mg} / \mathrm{L})$ & 1.0 & $\leq 5.0$ & 0.0018 & 0.0010 \\
\hline $\mathrm{Sb}(\mathrm{mg} / \mathrm{L})$ & 0.005 & 0.0061 & 0.014 & L.D. \\
\hline $\mathrm{Ba}(\mathrm{mg} / \mathrm{L})$ & 0.7 & 1.0 & L.D. & L.D. \\
\hline $\mathrm{Be}(\mathrm{mg} / \mathrm{L})$ & 0.002 & & 0.00007 & L.D. \\
\hline $\mathrm{B}(\mathrm{mg} / \mathrm{L})$ & 0.5 & 5.0 & 0.03713 & 0.000001 \\
\hline $\mathrm{Ni}(\mathrm{mg} / \mathrm{L})$ & 0.02 & & 0.00017 & L.D. \\
\hline $\mathrm{Tl}(\mathrm{mg} / \mathrm{L})$ & 0.0001 & & 0.00001 & L.D. \\
\hline
\end{tabular}

a: Standard of drinking water quality in China, GB 5749-2006;

b: Standard of drinking water quality in Canada, TEL;

c: Limit detection.

Table 5. Hg in the desalted water treated using the MED method was not detected; thus, its n-CR was neglected. The $n-C R$ values using the MED method were in the following descending order: $\mathrm{Cu}>\mathrm{Pb}>\mathrm{Ni}>\mathrm{Mn}>\mathrm{Zn}$. The total $n-C R$ values for the infant, teenager, adult and elderly populations were $8.12 \times 10^{-11}, 6.92 \times 10^{-11}$, $7.79 \times 10^{-11}$, and $6.66 \times 10^{-11} \mathrm{a}^{-1}$ respectively. The $\mathrm{n}-\mathrm{CR}$ values were 3-4 orders of magnitude lower than the neglectable risk level recommended by The Netherlands and England [21, 28], indicating that $n-C R$ caused by these metals could be neglected. For the RO method, $\mathrm{Pb}$ and $\mathrm{Cu}$ concentrations in the water samples were lower than the detection limit. Therefore, the $\mathrm{n}-\mathrm{CR}$ values only considered $\mathrm{Zn}, \mathrm{Mn}, \mathrm{Ni}$ and $\mathrm{Hg}$. The $\mathrm{n}-\mathrm{CR}$ values of the four metals followed the order $\mathrm{Hg}>\mathrm{Mn}>\mathrm{Ni}>\mathrm{Zn}$, which was different from the result using the MED method. By contrast, $\mathrm{Hg}$ was the most significant contributor to non-carcinogenic risks in the desalted water using the RO method. The $\mathrm{n}-\mathrm{CR}$ value of $\mathrm{Hg}$ was an order of magnitude higher than that of the other three metals. The total n-CR values based on the RO method were $3.23 \times 10^{-11}, 2.75 \times 10^{-11}, 3.09 \times 10^{-11}$, and $2.65 \times 10^{-11} \mathrm{a}^{-1}$ for the four sensitive groups, respectively; the values were all lower than that based on the MED method. Thus, the $n-C R$ values using both desalination methods were neglected.

The $\mathrm{CR}$ values of $\mathrm{Cd}$, As and $\mathrm{Cr}$ in the desalted water using the MED and RO methods are also exhibited in Table 5. The CR values of the three metals using the MED method were in the following order: $\mathrm{Cr}>\mathrm{As}>\mathrm{Cd}$. The $\mathrm{CR}$ values of $\mathrm{Cr}$ and $\mathrm{As}$ were two orders of magnitude higher than that of $\mathrm{Cd}$. The result was similar to the $\mathrm{CR}$ value in the drinking water in Beijing [29]. The total $C R$ values for trace metals using the MED method were $4.71 \times 10^{-5}$, $4.01 \times 10^{-5}, 4.52 \times 10^{-5}$, and $3.87 \times 10^{-5} \mathrm{a}^{-1}$ for infant, teenager, adult, and elderly populations, respectively. The CR values using the MED method were above the maximal acceptable risk levels designed by the Netherlands, Sweden and England $\left(1 \times 10^{-6} \mathrm{a}^{-1}\right)$, but in the range of the maximum allowed value provided by the International Commission on Radiological Protection

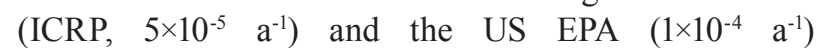
(Table 6). Regarding the RO method, Cd and As were not detected. Therefore, the CR was only caused by Cr. The $\mathrm{CR}$ values of $\mathrm{Cr}$ were $1.81 \times 10^{-6}, 1.54 \times 10^{-6}$, $1.73 \times 10^{-6}$, and $1.48 \times 10^{-6} \mathrm{a}^{-1}$ for the four stages of life. Similar to the result using the MED method, the risks were lower than the maximum limits recommended by ICRP and the US EPA.

The total risks of the trace metals using the MED and RO methods are shown in Fig. 1. According to the assessment result, the total health risks of the trace metals in the desalted water using the MED method for infant, teenager, adult and elderly populations were $4.71 \times 10^{-5}, 4.01 \times 10^{-5}, 4.52 \times 10^{-5}$, and $3.87 \times 10^{-5} \mathrm{a}^{-1}$, respectively. The total risks of the trace metals using the RO method were $1.81 \times 10^{-6}, 1.54 \times 10^{-6}, 1.73 \times 10^{-6}$, 
Table 5. Carcinogenic and non-carcinogenic risks of metals through drinking water in the desalted water using the MED and RO method $\left(a^{-1}\right)$.

\begin{tabular}{|c|c|c|c|c|}
\hline & Infant & Teenager & Adult & The elderly \\
\hline \multicolumn{5}{|c|}{ MED method } \\
\hline \multicolumn{5}{|c|}{ Non-carcinogens } \\
\hline $\mathrm{Pb}$ & $5.99 \mathrm{E}-12$ & $5.10 \mathrm{E}-12$ & $5.74 \mathrm{E}-12$ & $4.91 \mathrm{E}-12$ \\
\hline $\mathrm{Zn}$ & $4.30 \mathrm{E}-12$ & $3.66 \mathrm{E}-12$ & 4.12E-12 & $3.52 \mathrm{E}-12$ \\
\hline $\mathrm{Cu}$ & $5.64 \mathrm{E}-11$ & $4.80 \mathrm{E}-11$ & $5.41 \mathrm{E}-11$ & $4.63 \mathrm{E}-11$ \\
\hline $\mathrm{Mn}$ & $8.69 \mathrm{E}-12$ & $7.40 \mathrm{E}-12$ & 8.33E-12 & 7.13E-12 \\
\hline $\mathrm{Ni}$ & $5.83 \mathrm{E}-12$ & $4.96 \mathrm{E}-12$ & $5.59 \mathrm{E}-12$ & $4.78 \mathrm{E}-12$ \\
\hline Total n-CR & $8.12 \mathrm{E}-11$ & $6.92 \mathrm{E}-11$ & $7.79 \mathrm{E}-11$ & $6.66 \mathrm{E}-11$ \\
\hline \multicolumn{5}{|c|}{ Carcinogens } \\
\hline $\mathrm{Cd}$ & $1.02 \mathrm{E}-07$ & $8.70 \mathrm{E}-08$ & $9.80 \mathrm{E}-08$ & 8.39E-08 \\
\hline As & $1.44 \mathrm{E}-05$ & $1.23 \mathrm{E}-05$ & $1.38 \mathrm{E}-05$ & $1.18 \mathrm{E}-05$ \\
\hline $\mathrm{Cr}$ & $3.26 \mathrm{E}-05$ & $2.78 \mathrm{E}-05$ & $3.13 \mathrm{E}-05$ & $2.68 \mathrm{E}-05$ \\
\hline Total CR & 4.71E-05 & 4.01E-05 & $4.52 \mathrm{E}-05$ & $3.87 \mathrm{E}-05$ \\
\hline Total health risk & 4.71E-05 & 4.01E-05 & $4.52 \mathrm{E}-05$ & $3.87 \mathrm{E}-05$ \\
\hline \multicolumn{5}{|c|}{ RO method } \\
\hline \multicolumn{5}{|c|}{ Non-carcinogens } \\
\hline $\mathrm{Zn}$ & $2.32 \mathrm{E}-12$ & $1.98 \mathrm{E}-12$ & $2.23 \mathrm{E}-12$ & $1.90 \mathrm{E}-12$ \\
\hline $\mathrm{Mn}$ & $6.36 \mathrm{E}-12$ & $5.41 \mathrm{E}-12$ & $6.09 \mathrm{E}-12$ & $5.21 \mathrm{E}-12$ \\
\hline $\mathrm{Ni}$ & $4.28 \mathrm{E}-12$ & $3.65 \mathrm{E}-12$ & $4.11 \mathrm{E}-12$ & $3.51 \mathrm{E}-12$ \\
\hline $\mathrm{Hg}$ & $1.93 \mathrm{E}-11$ & $1.64 \mathrm{E}-11$ & $1.85 \mathrm{E}-11$ & $1.58 \mathrm{E}-11$ \\
\hline Total n-CR & $3.23 \mathrm{E}-11$ & $2.75 \mathrm{E}-11$ & $3.09 \mathrm{E}-11$ & $2.65 \mathrm{E}-11$ \\
\hline \multicolumn{5}{|c|}{ Carcinogens } \\
\hline $\mathrm{Cr}$ & $1.81 \mathrm{E}-06$ & $1.54 \mathrm{E}-06$ & $1.73 \mathrm{E}-06$ & $1.48 \mathrm{E}-06$ \\
\hline Total CR & $1.81 \mathrm{E}-06$ & $1.54 \mathrm{E}-06$ & $1.73 \mathrm{E}-06$ & $1.48 \mathrm{E}-06$ \\
\hline Total health risk & $1.81 \mathrm{E}-06$ & $1.54 \mathrm{E}-06$ & $1.73 \mathrm{E}-06$ & $1.48 \mathrm{E}-06$ \\
\hline
\end{tabular}

and $1.48 \times 10^{-6} \mathrm{a}^{-1}$, respectively. The health risk using the MED method was higher than that using the RO method. Overall, the $\mathrm{n}-\mathrm{CR}$ and $\mathrm{CR}$ for the four stages of life were in the descending order of infant $>$ adult $>$ teenager $>$ elderly population. The results suggest that infants are the most sensitive population among human beings; they need more attention. The result was similar to that of Geng et al. [21]. Additionally, the order of magnitude for the total n-CR was $10^{-11}$, indicating that $\mathrm{n}-\mathrm{CR}$ in both sites can be

Table 6. The maximal acceptable risk level and neglectable level recommended by some organizations $\left(\mathrm{a}^{-1}\right)[18,23]$.

\begin{tabular}{|c|c|c|c|}
\hline Organizations & Maximum allowed risk level & Neglectable level & Comments \\
\hline US EPA & $1 \times 10^{-4}$ & - & Radiation \\
\hline ICRP & $5 \times 10^{-5}$ & - & Chemical Contaminants \\
\hline Netherland & $1 \times 10^{-6}$ & $1 \times 10^{-8}$ & Chemical Contaminants \\
\hline Sweden & $1 \times 10^{-6}$ & - & - \\
\hline England & $1 \times 10^{-6}$ & $1 \times 10^{-7}$ & \\
\hline
\end{tabular}




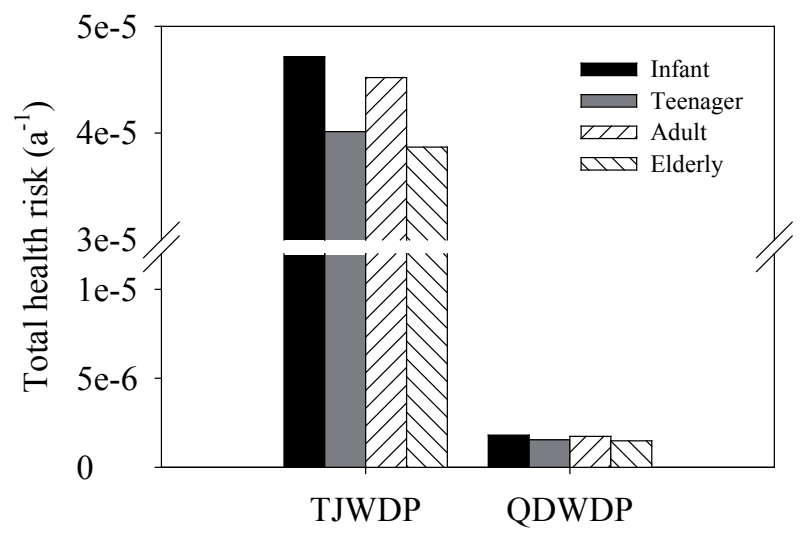

Fig. 1. Total health risks of trace metals in desalination water to four sections of the population using the MED and RO methods.

neglected. By comparison, the values of $\mathrm{CR}$ exceeded the limit value recommended by some countries. The results demonstrated that the non-carcinogenic metals rarely have harmful effects on human beings. The main risk came from the $\mathrm{CR}$. Among the carcinogenic metals, $\mathrm{Cr}$ was the major contributor to health risk. According to part 3.1, the concentrations of $\mathrm{Cr}$ in both sites were within the standard for drinking water, but their CR cannot be ignored. The phenomenon was caused by its high carcinogenic factor $\left(\mathrm{q}_{\mathrm{Cr}}=41\right)$. Therefore, it is imperative to assess the health risk of metals in drinking water.

\section{Conclusions}

The RO and MED methods were both efficient in the removal of ions and trace metals, while some metals were not efficiently removed ( $\mathrm{Hg}$ for the $\mathrm{RO}$ method and $\mathrm{Zn}$ for the MED method). The trace metal concentrations in the treated seawater all reached the drinking water standard in China (GB 57492006). After desalination, according to the trace metal concentrations in the desalinated water, the RO method might be better than the MED method. For both methods, the $n-C R$ values for the trace metals in the desalted water were within the neglectable level, while the $C R$ values were higher than the maximal acceptable risk levels designed by some countries and institutions. The total health risk using the MED method (the order magnitude is $10^{-5}$ ) was higher than that using the RO method (the order magnitude is $10^{-6}$ ). In addition, infants needed more attention due to their sensitivity. Although $\mathrm{Cr}$ has a low concentration in desalinated water, it was the major contributor to health risk due to its high carcinogenic factor. Evaluation of the health risks of metals is imperative in drinking water. Both seawater desalination methods are safe for drinking water.

\section{Acknowledgements}

This work was jointly supported by the National Key R\&D Program of China (2016YFC0401405) and the Research and Development Support Program of China Institute of Water Resources and Hydropower Research (WE0145B662017, WE0145B062017).

\section{Conflicts of Interest}

The authors declare no conflicts of interest.

\section{References}

1. LIU S.Y., ZHANG G.X., HAN M. Y., WU X.D., LI, Y. L., CHEN, K., MENG, J., SHAO, L., WEI, W. D., CHEN, G.Q. Freshwater costs of seawater desalination: Systems process analysis for the case plant in China. Journal of Cleaner Production, 212, 677, 2019.

2. ANIS S., HASHAIKEH R., HILAL N. Functional materials in desalination: A review. Desalination, 468, 114077, 2019.

3. LUO W., PHAN H.V., LI G., HAI F.I., PRICE W.E., ELIMELECH M., NGHIEM L.D. An osmotic membrane bioreactor-membrane distillation system for simultaneous wastewater reuse and seawater desalination: performance and implications. Environmental science \& technology, 51 (24), 14311, 2017.

4. LIU T.K., WENG T.H., SHEU, H.Y. Exploring the environmental impact assessment commissioners' perspectives on the development of the seawater desalination project. Desalination, 428, 108, 2018.

5. Global Water Intelligence (GWI), IDA Desalination Yearbook, 2016-2017, Media Analytics, Oxford, UK, 2017.

6. SCHIERMEIER Q. Water: purification with a pinch of salt. Nature, 7185 (452), 260, 2008,

7. ZOU Q., LIU, X.. Economic effects analysis of seawater desalination in China with input-output technology. Desalination, 380, 18, 2016.

8. National Development and Reform Commission of People's Republic of China. The 13th Five-year Plan for the Utilization of Seawater in China. http://www.ndrc.gov. cn/zcfb/zcfbghwb/201612/t20161230 833749.html. 2016.

9. SANO Y., BAI X., AMAGAI S., NĀKAYAMA A. Effect of a porous spacer on the limiting current density in an electro-dialysis desalination. Desalination, 444, 151, 2018.

10. QASIM M., BADRELZAMAN M., DARWISH N. N., DARWISH N.A., HILAL N., Reverse osmosis desalination: A state-of-the-art review. Desalination, 459, 59, 2019.

11. GAO C.J. Brief discussion of seawater desalination. Chem. Technol. Econom. 11, 24, 2003.

12. ZHENG X., CHEN D., WANG Q., ZHANG Z. Seawater desalination in China: Retrospect and prospect. Chemical Engineering Journal, 242, 404, 2014.

13. YANG H.L., LIN J.C., HUANG C. Application of nanosilver surface modification to RO membrane and spacer for mitigating biofouling in seawater desalination. Water Research, 43, 3777, 2009.

14. LIN L., XU X., PAPELIS C., XU P. Innovative use of drinking water treatment solids for heavy metals removal from desalination concentrate: Synergistic effect of 
salts and natural organic matter. Chemical Engineering Research and Design, 120, 231, 2017.

15. SHAHZAD M.W., BURHAN M., ANG L., NG K.C. Energy-water-environment nexus underpinning future desalination sustainability. Desalination, 413, 52, 2017.

16. YOON J., DO V.Q., PHAM V.S., HAN J. Return flow ion concentration polarization desalination: A new way to enhance electromembrane desalination. Water research, 159, 501, 2019.

17. MAIA C.B., SILVA F.V., OLIVEIRA V.L., KAZMERSKI L.L. An overview of the use of solar chimneys for desalination. Solar Energy, 183, 83, 2019.

18. LINARES R.V., LIZ., QUINTANIILLA Y.V., GHAFFOUR N., AMY G., LEIKNES T., VROUWENVELDER J.S. Life cycle cost of a hybrid forward osmosis e low pressure reverse osmosis system for seawater desalination and wastewater recovery. Water Research, 88, 225, 2016.

19. USEPA. Guidelines for Exposure Assessment, Washington DC: Office of Health and Environmental Assessment. 1992.

20. XIAO J., WANG L., DENG L., JIN Z. Characteristics, sources, water quality and health risk assessment of trace elements in river water and well water in the Chinese Loess Plateau. Science of the Total Environment, 650, 2004, 2019.

21. GENG M., QI H., LIU X., GAO B., YANG Z., LU W., SUN R. Occurrence and health risk assessment of selected metals in drinking water from two typical remote areas in China. Environmental Science and Pollution Research, 23, 8462, 2016.
22. WAKIL SHAHZAD M., BURHAN M., ANG L., CHOON NG. K. Energy-water-environment nexus underpinning future desalination sustainability. Desalination, 413, 52, 2017.

23. XUE R., WANG X.D. Research on the corrosion of the cast iron pipeline in the desaltnation. Tianjin Chemical Industry, 28, 36, 2014 [In Chinese].

24. ALI S., REHMAN S.A.U., LUAN H.Y., FARID M.U., HUANG $\mathrm{H}$. Challenges and opportunities in functional carbon nanotubes for membrane-based water treatment and desalination. Science of the Total Environment, 646, 1126, 2019.

25. SHANMUGANATHAN S., LOGANATHAN P., KAZNER C., JOHIR M.A.H., VIGNESWARAN S. Submerged membrane filtration adsorption hybrid system for the removal of organic micropollutants from a water reclamation plant reverse osmosis concentrate. Desalination, 401, 1341, 2017.

26. GB 5749-2006. Standard of drinking water quality. 2006.

27. Health Canada. Guidelines for Canadian Drinking Water Quality. 2012.

28. ZHAO X., LI T.Y., ZHANG T.T., LUO W.J., LI J.Y. Distribution and health risk assessment of dissolved heavy metals in the Three Gorges Reservoir, China (section in the main urban area of Chongqing). Environmental Science and Pollution Research, 24, 2697, 2017.

29. GAO J.J., ZHANG L.P., HUANG S.B., MA M., WANG Z.J. Preliminary health risk assessment of heavy metals in drinking waters in Beijing. Environmental Science, 25, 47, 2004. 